\title{
EVALUATION OF THE KNOWLEDGE ON COST OF ORTHOPEDIC IMPLANTS AMONG ORTHOPEDIC SURGEONS
}

\author{
Gustavo Gonçalves Arlanil ${ }^{1}$, Rodrigo Guerra Sabongl ${ }^{1}$, alysson Ferreira Batista ${ }^{1}$, \\ Diego Costa Astur ${ }^{1}$, Guilherme Guadagnini Falotico $^{1}$, Molses Cohen ${ }^{1}$
}

1. Universidade Federal de São Paulo, Department of Orthopedics and Traumatology, Sports Traumatology Center, São Paulo, SP, Brazil.

\section{ABSTRACT}

Objective: To determine the knowledge of Brazilian Orthopedic Surgeons on the costs of orthopedic surgical devices used in surgical implants. Methods: A questionnaire was applied to Brazilian Orthopedic Surgeons during the $46^{\text {th }}$ Brazilian Congress on Orthopedics and Traumatology. Results: Two hundred and one Orthopedic Surgeons completely filled out the questionnaire. The difference between the average prices estimated by the surgeons and the average prices provided by the supplier companies was $47.1 \%$. No differences were found between the orthopedic specialists and other subspecialties on the prices indicated for specific orthopedic implants. However, differences were found among orthopedic surgeons who received visits from representatives of implant companies and those who did not receive those visits on prices indicated for shaver and radiofrequency device. Correlation was found between length of orthopedic experience and prices indicated for shaver and interference screw, and higher the experience time the lower the price indicated by Surgeons for these materials. Conclusion: The knowledge of Brazilian Orthopedic Surgeons on the costs of orthopedic implants is precarious. Reduction of cost of orthopedics materials depends on a more effective communication and interaction between doctors, hospitals and supplier companies with solid orientation programs and awareness for physicians about their importance in this scenario. Level of Evidence III, Cross-Sectional Study.

Keywords: Prosthesis implantation. Cost control. Cost savings. Hospital costs. Orthopedics.

Citation: Arliani GG, Sabongi RG, Batista AF, Astur DC, Falotico GG, Cohen M. Evaluation of the knowledge on cost of orthopedic implants among orthopedic surgeons. Acta Ortop Bras. [online]. 2016;24(4):217-21. Available from URL: http://www.scielo.br/aob.

\section{INTRODUCTION}

Orthopaedics and Traumatology is the specialty of medicine responsible for the diagnosis and treatment of trauma to the skeletal muscles of the human body structures, as well as other disorders of the locomotor system. The word Orthopedics comes from the Greek, where "ortho" means straight, right and "pedics", child.

The enormous importance of the specialty comes from the pain-relieving capacity, restoration of function and correction of patients' deformities through the various existing orthopedic treatments. In recent decades there have been significant advances in the area with the advent of increasingly less invasive techniques for patients. These changes are only possible due to the appearance, innovation and improvement of the surgical orthopedics materials sector. ${ }^{1}$ However, these new technologies may be the most responsible for the abrupt and constant increasing costs in healthcare. For these expenses to be controlled and better managed it is important that administrators, nurses, health insu- rance plans and particularly physicians have complete science of the amounts involved in health procedures. ${ }^{2}$

Previous studies, however, showed that orthopedic surgeons often do not have an exact idea of the values of orthopedics materials used in surgeries. ${ }^{3-5}$ Several studies have been conducted in recent years assessing the prospects and trends of Brazilian orthopedic surgeons. But all these studies had as main theme orthopedic conditions and did not address health management and costs. ${ }^{6-8}$

Therefore, the aim of this study is to determine the knowledge of Brazilian orthopedic surgeons on the cost of implants used in many orthopedic surgical procedures.

\section{METHODS}

This is a descriptive study using a questionnaire to a sample of orthopedic surgeons in Brazil. The questionnaire was prepared and approved by the authors so that it was very understanding and simple. It consisted of questions covering topics such as

All the authors declare that there is no potential conflict of interest referring to this article. 
practice time, number of surgeries per year performed in the public and private sectors, subspecialty of the surgeons and estimate price of many orthopedics materials. (Annex 1)

The questionnaire was applied to Brazilian orthopedic surgeons during the three days of the $46^{\text {th }}$ Brazilian Congress of Orthopedics and Traumatology. To resolve any questions while filling it, one of the authors of this paper was always present throughout the application period of the questionnaires. The prices of several orthopedics materials were requested for three different companies and an average price was obtained.

From the data from the questionnaires, a demographic descriptive statistics of the variables involved to characterize the sample was conducted. In order to perform a correlation between the orthopedics subspecialty within orthopedics and the prices indicated for orthopedics materials and a correlation between receiving visits from representatives of suppliers companies and the price of the materials, we used the Mann-Whitney test. In the correlation analysis between prices of materials $(R \$)$ and experience time of orthopedists we used the Spearman correlation coefficient. Data were analyzed using SPSS for Windows version 16.0 and a significance level of $5 \%$ was adopted. The study was approved by the Research Ethics Committee of Universidade Federal de São Paulo, São Paulo, SP, Brazil, under number 1.283.422.

\section{RESULTS}

In total, 201 orthopedic surgeons completely filled out the questionnaire and were part of the sample analyzed. Table 1 shows the geographic distribution of surgeons according to the region of origin. Regarding the surgeons' time of experience, we obtained an average of $7.4 \pm 8.8$ years (range 1-40 years). The results on the number of surgeries performed per year in the public and private sectors are shown in Table 2.

Table 1. Distribution of surgeons by region of origin $(n=201)$.

\begin{tabular}{c|c}
\hline Characteristics $-\mathbf{n}(\%)$ & $(\mathbf{n}=\mathbf{2 0 1 )}$ \\
\hline Region & \\
\hline Midwest & $13(6.5)$ \\
\hline Northeast & $31(15.4)$ \\
\hline North & $12(6.0)$ \\
\hline Southeast & $129(64.2)$ \\
\hline South & $16(8.0)$ \\
\hline
\end{tabular}

Table 2. Number of surgeries performed per year $(n=201)$.

\begin{tabular}{c|c}
\hline Characteristics $-\mathbf{n}(\%)$ & $(\mathbf{n}=201)$ \\
\hline Number of surgeries & \\
\hline 0 & $49(24.4)$ \\
\hline$<10$ & $45(22.4)$ \\
\hline 10 a 20 & $21(10.4)$ \\
\hline 20 a 30 & $9(4.5)$ \\
\hline 30 a 40 & $10(5.0)$ \\
\hline$>40$ & $67(33.3)$ \\
\hline
\end{tabular}

The more frequent Orthopedics subspecialties among the orthopedic surgeons were: Traumatology (19.9\%); Knee (19.4\%); Hip (8.5\%) and Shoulder and Elbow (7.0\%). When asked whether they were visited by representatives of orthopedic implant companies, $51.5 \%$ reported receiving visits from representatives of those companies.

The prices indicated by orthopedic surgeons for various orthopedics materials and the suppliers of orthopedic implants are shown in Tables 3 and 4.

The mean difference between the average prices expected by the surgeons and the average prices provided by the companies was $47.1 \%$. This was a positive difference, i.e., the average prices given by most physicians were higher than the average commercial prices for the following materials: shaver (71.8\%), anchor (11.6\%), radiofrequency (54.5\%) and interference screw (25.1\%). As for the other materials (total knee prosthesis, total hip prosthesis and locked intramedullary nail of the tibia), the difference was negative, respectively, $63.8 \%, 66.7 \%$ and $36.6 \%$. No significant differences were found between orthopedic specialists and other subspecialties regarding prices indicated for specific orthopedics materials. (Table 5)

Table 3. Prices $(\mathrm{R} \$)$ indicated as probable by orthopedists.

\begin{tabular}{|c|c|}
\hline Materials & $(\mathrm{n}=201)$ \\
\hline \multicolumn{2}{|l|}{ Total knee prosthesis } \\
\hline mean (Standard deviation) & $14281.09(11811.20)$ \\
\hline median & 10000 \\
\hline minimum - maximum & $1500.00-100000.00$ \\
\hline \multicolumn{2}{|l|}{ Total hip prosthesis } \\
\hline mean (Standard deviation) & $16622.89(13906.86)$ \\
\hline median & 14000 \\
\hline minimum - maximum & $1000.00-100000.00$ \\
\hline \multicolumn{2}{|l|}{ Shaver } \\
\hline mean (Standard deviation) & $2838.31(4965.69)$ \\
\hline median & 1500 \\
\hline minimum - maximum & $200.00-60000.00$ \\
\hline \multicolumn{2}{|l|}{ Interference Screw } \\
\hline mean (Standard deviation) & 2359.45 (3277.99) \\
\hline median & 1500 \\
\hline minimum - maximum & $50.00-30000.00$ \\
\hline \multicolumn{2}{|l|}{ Radiofrequency } \\
\hline mean (Standard deviation) & $4252.49(8982.63)$ \\
\hline median & 2000 \\
\hline minimum - maximum & $100.00-100000.00$ \\
\hline \multicolumn{2}{|l|}{ Locked Intramedullary Nail } \\
\hline mean (Standard deviation) & $9493.08(56292.01)$ \\
\hline median & 4000 \\
\hline minimum - maximum & $110.00-800150.00$ \\
\hline \multicolumn{2}{|l|}{ Anchor } \\
\hline mean (Standard deviation) & $2752.14(3256.61)$ \\
\hline median & 2000 \\
\hline minimum - maximum & $100.00-25000.00$ \\
\hline
\end{tabular}




\begin{tabular}{|c|c|}
\hline Materials & \\
\hline \multicolumn{2}{|l|}{ Total knee prosthesis } \\
\hline mean & 23390 \\
\hline minimum - maximum & $18000-29820$ \\
\hline \multicolumn{2}{|l|}{ Total hip prosthesis } \\
\hline mean & 27717 \\
\hline minimum - maximum & $25000-32000$ \\
\hline \multicolumn{2}{|l|}{ Shaver } \\
\hline mean & 800 \\
\hline minimum - maximum & $500-1200$ \\
\hline \multicolumn{2}{|l|}{ Interference Screw } \\
\hline mean & 1767 \\
\hline minimum - maximum & $1000-2800$ \\
\hline \multicolumn{2}{|l|}{ Radiofrequency } \\
\hline mean & 1933 \\
\hline minimum - maximum & $1400-2400$ \\
\hline \multicolumn{2}{|l|}{ Locked Intramedullary Nail } \\
\hline mean & 14977 \\
\hline minimum - maximum & $11400-19080$ \\
\hline \multicolumn{2}{|l|}{ Anchor } \\
\hline mean & 2433 \\
\hline minimum - maximum & $1500-3800$ \\
\hline
\end{tabular}

Significant differences were found between the orthopedists who receive visits from companies representatives and those who did not regarding prices indicated for shaver $(p=0.028)$ and radio frequency $(p=0.033)$. The orthopedic surgeons who received visits indicated lower prices for the same materials. (Table 6)

Significant correlation coefficients were found between the time of experience of orthopedic surgeons and prices indicated for the shaver $(r=-0.30 p<0.001)$ and interference screw $(r=-0.19 p=0.007)$. The coefficients are negative, indicating that the higher experience time, the lower the price indicated for these materials. (Table 7)

\section{DISCUSSION}

The main result of this study is the low awareness of orthopedic surgeons on the prices of materials used in surgical procedures. This is a worrying result, as $60 \%$ of health-related costs are controlled by the doctors' decisions, although they receive little information and training on actions and strategies to reduce these costs. ${ }^{9}$

Streit et al. ${ }^{4}$ in a study that applied questionnaires to orthopedic surgeons, showed that the error in the estimate of orthopedics materials prices was $69 \%$, and most of these errors (67\%) underestimated the prices of orthopedics materials. Another study Acta Ortop Bras. 2016;24(4):217-21
Table 5. Prices of materials $(\mathrm{R} \$$ ) according to the orthopedists subspecialties.

\begin{tabular}{|c|c|c|}
\hline $\begin{array}{l}\text { Prices indicated } \\
\text { as probable by }\end{array}$ & \multicolumn{2}{|c|}{ Orthopedists } \\
\hline Total knee prosthesis & $\begin{array}{c}\text { Not knee specialist } \\
\quad(n=162)\end{array}$ & $\begin{array}{l}\text { Knee specialist } \\
\quad(n=39)\end{array}$ \\
\hline $\begin{array}{c}\text { mean } \\
\text { (Standard deviation) }\end{array}$ & $14472,22(12454,42)$ & $13487,18(8731,74)$ \\
\hline median & 10000 & 12000 \\
\hline minimum - maximum & $1500,00-100000,00$ & $1500,00-50000,00$ \\
\hline $\begin{array}{c}p \text {-value } \\
\text { (Mann-Whitney test) }\end{array}$ & 0,687 & \\
\hline Total hip prosthesis & $\begin{array}{l}\text { Not hip specialist } \\
\qquad(n=184)\end{array}$ & $\begin{array}{l}\text { Hip specialist } \\
\text { (n=17) }\end{array}$ \\
\hline $\begin{array}{c}\text { mean } \\
\text { (Standard deviation) }\end{array}$ & $16758,15(14307,99)$ & $15158,82(8576,35)$ \\
\hline median & 14000 & 12000 \\
\hline minimum - maximum & $1000,00-100000,00$ & $3000,00-35000,00$ \\
\hline $\begin{array}{c}\text { p-value } \\
\text { (Mann-Whitney test) }\end{array}$ & 0,786 & \\
\hline $\begin{array}{l}\text { Locked Intramedullary } \\
\text { Nail }\end{array}$ & $\begin{array}{l}\text { Not trauma specialist } \\
\qquad(n=161)\end{array}$ & $\begin{array}{l}\text { Trauma specialist } \\
\qquad(n=40)\end{array}$ \\
\hline $\begin{array}{c}\text { mean } \\
\text { (Standard deviation) }\end{array}$ & $62854,74(10142,61)$ & $6878,75(5777,46)$ \\
\hline median & 4000 & 5000 \\
\hline minimum - maximum & $110,00-800150,00$ & $850,00-25000,00$ \\
\hline $\begin{array}{c}\text { p-value } \\
\text { (Mann-Whitney test) }\end{array}$ & 0,059 & \\
\hline
\end{tabular}

on orthopedic implants costs showed that only $21 \%$ of doctors estimated correctly the values of the materials provided by empresas. 5 In this study the difference between the prices estimated by doctors and the actual price provided by companies was $47 \%$; there was both underestimation and overestimation of prices by the surgeons in, respectively, 3 and 4 types of orthopedics materials.

Burns et al. ${ }^{2}$ showed a close and long term relationship between surgeons and implant manufacturers. However, only a small part of the orthopedic surgeons received financial payments from supplier companies. ${ }^{2,10}$ In Brazil, in our surgeons' sample, more than half (51.5\%) reported receiving visits from representatives of orthopedic implant companies. However, differences were only found between the orthopedists who received visits from representatives of companies and those who did not. Considering shaver and radiofrequency, the orthopedic surgeons visited by commercial representatives underestimated their prices.

Okike et al. ${ }^{5}$ showed that medical residents thought they had worse knowledge on the costs of orthopedic implants that more experienced doctors. This study found differences between the experience time of orthopedists and prices listed for some materials; the longer the surgeons' experience time, the lower the price indicated for some materials. However, no differences 


\begin{tabular}{|c|c|c|}
\hline \multirow[t]{2}{*}{ Materials } & \multicolumn{2}{|c|}{ Receive visits from companies representatives } \\
\hline & Yes $(n=103)$ & No $(n=97)$ \\
\hline \multicolumn{3}{|l|}{ Total knee prosthesis } \\
\hline $\begin{array}{c}\text { mean } \\
\text { (Standard deviation) }\end{array}$ & $13087.38(9145.19)$ & $15438.14(14060.37)$ \\
\hline median & 10000 & 10000 \\
\hline minimum - maximum & $1500.00-50000.00$ & $1500.00-100000.00$ \\
\hline $\begin{array}{c}p \text {-value } \\
\text { (Mann-Whitney test) }\end{array}$ & 0.58 & \\
\hline \multicolumn{3}{|l|}{ Total hip prosthesis } \\
\hline $\begin{array}{c}\text { mean } \\
\text { (Standard deviation) } \\
\end{array}$ & $16249.51(14435.62)$ & $16675.26(13028.82)$ \\
\hline median & 12000 & 15000 \\
\hline minimum - maximum & $1500.00-100000.00$ & $1000.00-80000.00$ \\
\hline $\begin{array}{c}\mathrm{p} \text {-value } \\
\text { (Mann-Whitney test) }\end{array}$ & 0.625 & \\
\hline \multicolumn{3}{|l|}{ Shaver } \\
\hline $\begin{array}{c}\text { mean } \\
\text { (Standard deviation) }\end{array}$ & $2383.50(3171.26)$ & $3340.21(6338.28)$ \\
\hline median & 1500 & 2000 \\
\hline minimum - maximum & $200.00-20000.00$ & $200.00-60000.00$ \\
\hline $\begin{array}{c}p \text {-value } \\
\text { (Mann-Whitney test) }\end{array}$ & 0.028 & \\
\hline \multicolumn{3}{|l|}{ Interference screw } \\
\hline $\begin{array}{c}\text { mean } \\
\text { (Standard deviation) }\end{array}$ & $2430.58(3682.71)$ & $2305.15(2814.83)$ \\
\hline median & 1500 & 1500 \\
\hline minimum - maximum & $200.00-30000.00$ & $50.00-20000.00$ \\
\hline $\begin{array}{c}\mathrm{p} \text {-value } \\
\text { (Mann-Whitney test) }\end{array}$ & 0.891 & \\
\hline \multicolumn{3}{|l|}{ Radiofrequency } \\
\hline $\begin{array}{c}\text { mean } \\
\text { (Standard deviation) }\end{array}$ & $3207.77(5629.46)$ & $5400.52(11479.48)$ \\
\hline median & 1800 & 2000 \\
\hline minimum - maximum & $100.00-40000.00$ & $300.00-100000.00$ \\
\hline $\begin{array}{c}\mathrm{p} \text {-value } \\
\text { (Mann-Whitney test) }\end{array}$ & 0.033 & \\
\hline \multicolumn{3}{|l|}{$\begin{array}{c}\text { Locked Intramedullary } \\
\text { nail }\end{array}$} \\
\hline $\begin{array}{c}\text { mean } \\
\text { (Standard deviation) } \\
\end{array}$ & $4660.29(3426.30)$ & $6473.71(6560.79)$ \\
\hline median & 4000 & 4000 \\
\hline minimum - maximum & $110.00-20000.00$ & $300.00-30000.00$ \\
\hline $\begin{array}{l}\text { p-value (Mann-Whitney } \\
\text { test) }\end{array}$ & 0.307 & \\
\hline \multicolumn{3}{|l|}{ Anchor } \\
\hline $\begin{array}{c}\text { mean } \\
\text { (Standard deviation) }\end{array}$ & 2402.91 (2739.52) & 3148.25 (3710.63) \\
\hline median & 1800 & 2000 \\
\hline minimum - maximum & $300.00-25000.00$ & $100.00-25000.00$ \\
\hline $\begin{array}{c}\mathrm{p} \text {-value } \\
\text { (Mann-Whitney test) }\end{array}$ & 0.18 & \\
\hline
\end{tabular}

\begin{tabular}{|c|c|c|}
\hline $\begin{array}{c}\text { Probable prices indicated } \\
\text { by orthopedists ( } R \$)\end{array}$ & $\begin{array}{l}\text { Spearmen correlation } \\
\text { coefficient }(r)\end{array}$ & $\mathrm{p}$-value \\
\hline Total knee prosthesis & 0.14 & 0.051 \\
\hline Total hip prosthesis & 0.09 & 0.227 \\
\hline Shaver & -0.3 & $<0.001$ \\
\hline Interference screw & -0.19 & 0.007 \\
\hline Radiofrequency & -0.09 & 0.189 \\
\hline Locked intramedullary nail & -0.01 & 0.874 \\
\hline Anchor & -0.03 & 0.629 \\
\hline
\end{tabular}

were found regarding the subspecialty referred by the orthopedic surgeons and the prices indicated for orthopedics materials specific for this particular subspecialty.

Despite the increasing costs in health care, a study published by the American Society of Orthopaedic Surgeons showed that most surgeons did not consider themselves responsible for containing health costs. ${ }^{11}$ We do know, however, that physicians have a key role in this economic process and in reducing health costs. A previous study showed that $85 \%$ of patients proved willing to pay additional amounts for best quality materials indicated by doctors even whether they were not covered by health insurance plans. ${ }^{12}$ While cost containment is critical to the viability and maintenance of health systems, care should be taken to ensure that cost-effectiveness does not increase the number of complications and compromise the patient's outcomes. ${ }^{11,13}$

Closer cooperation between the various health stakeholders such as hospitals, doctors, health plans and orthopedic implant companies is required to achieve the goal of significantly reducing implant costs, maintaining the quality of services provided to patients. ${ }^{11}$

\section{CONCLUSION}

The knowledge of Brazilian orthopedic surgeons on the costs of orthopedic implants is feeble. Cost reduction of orthopedics materials depends on a more effective communication and interaction between doctors, hospitals and supplier companies with more solid orientation and awareness programs for physicians about their importance in this scenario.

AUTHORS' CONTRIBUTIONS: Each author contributed individually and significantly to the development of this study. GGA (00000003-4371-5041)* and DCA (0000-0001-9163-7979)* were the main contributors in the drafting of the manuscript. RGS (00000003-0164-3596)*, AFB (0000-0001-9057-2712)* and GGF applied the questionnaires and tabulated the data. GGF (0000-00024189-574X)* evaluated the data of statistical analysis. MC (0000-0001-7671-8113)*, RGS and AFB carried out the literature search. $\mathrm{MC}$ and GGA conducted the manuscript review and contributed to the intellectual concept of the study. ${ }^{*} \mathrm{ORCID}$ (Open Research and Contributor ID). 


\section{REFERENCES}

1. Hansen E, Bozic KJ. The impact of disruptive innovations in orthopaedics. Clin Orthop Relat Res. 2009;467(10):2512-20.

2. Burns LR, Housman MG, Booth RE Jr, Koenig A. Implant vendors and hospitals:competing influences over product choice by orthopedic surgeons. Health Care Manage Rev. 2009;34(1):2-18.

3. Rohman L, Hadi S, Whitwell G. Surgeons' knowledge about the costs of orthopaedic implants. J Orthop Surg (Hong Kong). 2014;22(2):221-3.

4. Streit JJ, Youssef A, Coale RM, Carpenter JE, Marcus RE. Orthopaedic surgeons frequently underestimate the cost of orthopaedic implants. Clin Orthop Relat Res.2013;471(6):1744-9.

5. Okike K, O'Toole RV, Pollak AN, Bishop JA, McAndrew CM, Mehta S, Cross WW 3rd, Garrigues GE, Harris MB, Lebrun CT. Survey finds few orthopedic surgeons know the costs of the devices they implant. Health Aff (Millwood). 2014;33(1):103-9.

6. Arliani GG, da Silva AV, Ueda LR, Astur DC, Yazigi Júnior JA, Cohen M. Reconstruction of the medial patellofemoral ligament in cases of acute traumatic dislocation of the patella: current perspectives and trends in Brazil. Rev Bras Ortop. 2014;49(5):499-506.
7. Astur DC, Novaretti JV, Uehbe RK, Arliani GG, Moraes ER, de Castro Pochini A, et al. Muscle injury: current perspectives and trends in Brazil. Rev Bras Ortop. 2014;49(6):573-80.

8. Arliani GG, Astur DC, Kanas M, Kaleka CC, Cohen M. Anterior cruciate ligament injury: treatment and rehabilitation. Current perspectives and trends. Rev Bras Ortop. 2012;47(2):191-6.

9. Agrawal S, Taitsman J, Cassel C. Educating physicians about responsible management of finite resources. JAMA. 2013;309(11):1115-6.

10. Robinson JC, Pozen A, Tseng S, Bozic KJ. Variability in costs associated with total hip and knee replacement implants. J Bone Joint Surg Am. 2012;94(18):1693-8.

11. Egol KA, Capriccioso CE, Konda SR, Tejwani NC, Liporace FA, Zuckerman JD,Davidovitch RI. Cost-effective trauma implant selection: AAOS exhibit selection. J Bone Joint Surg Am. 2014;96(22):e189.

12. Sharkey PF, Sethuraman V, Hozack WJ, Rothman RH, Stiehl JB. Factors influencing choice of implants in total hip arthroplasty and total knee arthroplasty: perspectives of surgeons and patients. J Arthroplasty. 1999;14(3):281-7.

13. Olson SA, Obremskey WT, Bozic KJ. Healthcare technology: physician collaboration in reducing the surgical cost. Clin Orthop Relat Res. 2013;471(6):1854-64.
1- Years of experience as an Orthopedist Surgeon: years

2- How many surgeries do you perform per year?

\begin{tabular}{c|c|c}
\hline Surgeries per year & Public Service & Private/Service \\
\hline$<10$ & & \\
\hline $10-20$ & & \\
\hline $20-30$ & & \\
\hline $30-40$ & & \\
\hline$>40$ & & \\
\hline
\end{tabular}

3- What do you think is the average price of a total knee prosthesis? Price: reais

4- What do you think is the average price of a total hip prosthesis? Price: reais

5- What do you think is the average price of a shaver blade for knee arthroscopy? Price: reais
6- What do you think is the average price of anmaterial interference screw for ACL fixation?

Price: reais

7- What do you think is the average price of a radiofrequency? Price: reais

8- What do you think is the average price of an intramedullary nail for osteosynthesis of a tibia fracture?

$$
\text { Price: }
$$

9- What do you think is the average price of an absorbable anchor suture? Price: reais

10- What is your subspecialty?

$\begin{array}{lll}\square \text { Spine } & \square \text { Shoulder/Elbow } & \square \text { hand } \\ \square \text { Hip } & \square \text { Knee } & \square \text { Foot/Ankle } \\ \square \text { Trauma } & \square \text { Tumor }\end{array}$

12- Do you frequently receive visits from sales representatives of orthopedics material?

$\square$ Yes Price: reais 